\title{
Vezljivost glagolov védenja v zgodovini slovenskega knjižnega jezika
}

\author{
Robert Grošelu \\ Univerza v Ljubljani, Filozofska fakulteta, Aškerčeva 2, \\ SI-1000Ljubljana, robert.groselj@ff.uni-lj.si
}

\begin{abstract}
Razprava obravnava vezljivost glagolov védenja, tj. umeti (z drugotnim nedovršnikom umevati), vedeti in znati, v zgodovini slovenskega knjižnega jezika. Raziskavo sestavljajo pomenska opredelitev glagolov, vzpostavitev pomenskih in vezavnostnih vzorcev, določitev njihove stabilnosti, razvojnih značilnosti in konkurenčnih razmerij. Po pomenih so primerjane vezljivostne značilnosti med glagoli.

The paper discusses the development of valency for the verbs of knowing, i.e., umeti (with its secondary imperfective umevati), vedeti and znati, in the history of Slovenian literary language. In the study the verb meanings are defined, within every meaning the semantic and government patterns are determined. The patterns are analysed as to their stability, developmental characteristics, and competition with one another. Within every meaning the valency characteristics of the analysed verbs are compared.
\end{abstract}

Ključne besede: zgodovina slovenščine, razvoj vezljivosti, vezava, glagoli védenja

Key words: history of Slovenian, development of valency, government, verbs of knowing

\section{Uvod $^{1}$}

V zgodovinski skladnji se redke raziskave posvečajo spremembam stavčnih vzorcev. Danes skušajo to vrzel zapolniti vezljivostne študije, ki spremembe vzorcev vidijo predvsem kot rezultat pomenskega in skladenjskega razvoja njihovih oblikovalcev, ki lahko v času različno oblikujejo svoje skladenjsko

${ }^{1}$ Razprava se navezuje na del avtorjeve disertacije Vezava glagolov umevanja $v$ slovanskih jezikih (mentorici red. prof. dr. Alenka Šivic-Dular, izr. prof. dr. Andreja Žele), obranjene februarja 2010 na Oddelku za slavistiko Filozofske fakultete Univerze v Ljubljani. 
okolje - ob sebi predvidevajo različne elemente, ki se pomensko in oblikovno spreminjajo (Heringer 2006: 1456-1460; Korhonen 2006: 1469-1471).

Tudi pričujoča razprava je posvečena tej problematiki, saj obravnava vezljivost védenjskih glagolov umeti ( $\mathrm{z}$ drugotnim nedovršnikom umevati), vedeti in znati $\mathrm{v}$ zgodovini slovenskega knjižnega jezika. Ker pa gre za pomensko sorodne glagole, so cilji analize večplastni: (1) poleg raznovrstnosti vezljivostnih zmožnosti glagolov bi rad predstavil tudi razmerja med njimi; s tem bi preveril, ali pomensko podobni glagoli res težijo k pojavljanju $\mathrm{v}$ enakih vezljivostnih zgradbah (Goldberg 2006: 58); (2) skušal bom dokazati, da se s spreminjanjem pomena glagolov spreminja tudi njihova vezljivost (Žele 2003); (3) z razpravo bi rad dopolnil dosedanja védenja o vezavi teh glagolov v slovenščini (Orzechowska 1972, 1974).

$\mathrm{V}$ ta namen so opredeljeni pomeni glagolov in - na podlagi besedilnih zgledov iz vseh obdobij knjižne slovenščine - določene njihove razvojne vezljivostne značilnosti. Po pomenih so oblikovani pomenski in vezavnostni vzorci, ki so obravnavani glede na stabilnost, razvojne značilnosti in konkurenčna razmerja. Po posameznih pomenih so primerjane vezljivostne značilnosti med glagoli.

\subsection{Gradivo in korpus}

0.1.1 Gradivo raziskave so sln. glagoli uméti (tudi drugotni nedov. umévati), védeti in znáti, ki se lahko pomensko (tudi etimološko) opredelijo kot védenjski.

Glagoli védenja imajo zanimive pomenske in skladenjske značilnosti, zaradi česar so predmet raznovrstnih, ne le jezikoslovnih obravnav. V kognitivnem jezikoslovju ima njihov osebek vlogo konceptualizatorja, ki oblikuje npr. vsebinski odvisnik in mu določa verjetnost. V teoriji mentalnih prostorov so tovrstni glagoli obravnavani kot mehanizmi, ki jih govorci uporabljajo za tvorbo drugotnih mentalnih prostorov (vsebinski odvisnik predstavlja drugotni mentalni prostor, ki je različno povezan z osnovnim; po García-Miguel idr. 2004: 401-402).

Glagoli védenja so zanimivi tudi zaradi raznovrstne realizacije vsebine, ki ima lahko (predložno)sklonsko obliko, obliko vsebinskega odvisnika, nedoločniškega polstavka, lahko pa je tudi zapletenejša, veččlenska (za slov. jezike npr. Orzechowska 1972, 1974; za češ. VV: 198-223; za šp. García-Miguel idr. 2004: 403-418).

0.1.2 Korpus sestavljajo besedilni zgledi iz slovarskih in neslovarskih del, ki pokrivajo vso zgodovino sln. knjižnega jezika in predknjižno obdobje (10.-21. st.; obsežno gradivo se pojavi s knjižnim obdobjem v drugi polovici 16. st.). Prim. vire na koncu razprave. ${ }^{2}$

\footnotetext{
${ }^{2}$ Zgledi z izpričanimi vezljivostnimi značilnostmi glagolov so bili na podlagi uveljavljenih zapisov (prim. SPP) oblikovani v pomenske in vezavnostne vzorce, primerne za vezljivostno analizo.
} 


\subsection{Metode}

0.2.1 Pomenska analiza glagolov temelji na pomenskih razlagah v slovarskih virih, ki se med seboj razlikujejo. Poskus njihove uskladitve (ki izhaja tudi iz preveritve zgledov) sloni na sintagmatskem načelu slovarskega pomena, ki izkazuje podredno razmerje pomenskih sestavin s skladenjsko vodilno uvrščevalno pomensko sestavino (UPS) in odvisnimi razločevalnimi pomenskimi sestavinami (RPS; Vidovič-Muha 2000: 53).

$\mathrm{Na}$ ta način se lahko vzpostavijo t. i. primerljivi pomeni, tj. pomeni z enako UPS in čim več prekrivnimi RPS, ki omogočajo primerjavo vezljivostnih možnosti med glagoli. Sistematizacija slovarskih virov in zgledov, ki temelji na zgodovinskorazvojnem urejevalnem načelu, pa omogoča opredelitev časovne ustaljenosti pomenov.

0.2.2 Vezljivostna analiza glagolov izhaja iz sodobnih vezljivostnih razprav (npr. Karolak 1984; VV; Žele 2001; prim. Ágel 2000; Herbst 2007, 2009). Vezljivost je zmožnost določene besede - nosilca vezljivosti, ${ }^{3}$ da napoveduje skladenjska mesta (družljivost označuje prosta mesta); po Th. Herbstu (2009: 53) gre za lastnost leksikalne enote, ki kaže na njen skladenjski potencial. Obvezna skladenjska mesta, ki jih napove pomenska usmerjenost oz. pomensko-skladenjska vezljivost glagola (z udeleženskimi vlogami), so zasedena s t. i. določili v določeni slovnični obliki (strukturnoskladenjska vezljivost; Žele 2001: 13). ${ }^{4}$

$\mathrm{Na}$ podlagi pomenov, kot so aktualizirani v besedilnih zgledih, ${ }^{5}$ se lahko izpostavijo pomenskoskladenjske značilnosti glagolov védenja v sln. Osrednjo vlogo imajo udeleženci - pomenske entitete, ki ustrezajo predmetnim ali abstraktnim sestavinam zunajjezikovne mikrosituacije, kot jo odraža pomen glagola; vsebino udeležencev pokrivajo udeleženske vloge, ki se jih lahko določi na podlagi pomena glagola, pomenskih in skladenjsko-oblikovnih lastnosti udeležencev (več v SČ: 38-41; Orešnik 1992; Götz-Votteler 2007; o udeležencih v pomenski podstavi stavka že Toporišič 1982: 225-226). Pomensko (vezljivostno) razmerje med udeleženci, ki ga usmerja nosilec vezljivosti, ponazarjajo pomenski (vezljivostni) vzorci, npr. nosilec védenja - vsebina (prim. vzorce v SPP, VSSG itn.; kompleksnejši opisi v García-Miguel idr. 2004: 403-418).

Pomenska usmerjenost se izrazno uresničuje v strukturnoskladenjski vezljivosti ali vezavi (po Dular 1982), ${ }^{6}$ ki predstavlja predvidljivost neslovarskih

\footnotetext{
${ }^{3}$ Najbolj tipični nosilci vezljivosti so glagoli, pridevniki (različna stanjska lastnostna razmerja), izglagolski in izpridevniški samostalniki (Žele 2001: 15).

${ }^{4}$ Glagoli v pomožniški vlogi kot slovničnofunkcijska jedra povedi v okviru strukturnoskladenjske vezljivosti uvajajo le neudeležensko povedkovodoločilno vezljivost (Žele 2001: 13).

${ }^{5} \mathrm{Za}$ (besedilno) aktualizacijo prim. Beaugrande-Dressler 1992 (33); o (besedilni) aktualizaciji denotata prim. tudi Vidovič-Muha 2000 (80).

${ }^{6}$ Vezavo (po Dular 1982) je treba ločevati od tradicionalnih opredelitev rekcije (npr. Toporišič 1982: 21).
} 
lastnosti določil (slovnična oblika) na podlagi slovarskih lastnosti nosilca vezljivosti (po Dular 1982: 78). Določila in zapletenejše določilne možnosti ${ }^{7}$ v določeni slovnični obliki (oblikoslovne, oblikoskladenjske kategorije tipa sklon, odvisnik) so prikazana s pomočjo t. i. vezavnostnih vzorcev, zapisov tipa SNom - VF - SENT (po pomenih). Vezavnostni vzorci torej predstavljajo možne kombinacije določil $\mathrm{v}$ okviru posameznega pomena nosilca vezljivosti (Herbst 2009: 56); kot ustrezne predstavitve skladenjskega obnašanja nosilcev vezljivosti so izpostavljeni v neslovanskem (npr. García-Miguel idr. 2004; Heringer 2006: 1451-1456; Herbst 2007: 18-25) in slovanskem jezikoslovju (npr. SSG; Karolak 1984; VV; Žele 2001). Po pomenih sta določena časovni lok in stabilnost pojavljanja vzorcev ${ }^{8}$ primerjane pa so tudi vezljivostne značilnosti med glagoli. Tako ne postanejo jasnejša le konkurenčna razmerja med glagoli, temveč tudi sama razvojna stabilnost pomenskih in vezavnostnih vzorcev. ${ }^{9}$

Posebna pozornost je namenjena določilom, ki jih spremljajo krajši oblikoskladenjski, pomenski ali etimološki opisi. Vezljivostnih sprememb ne povzroča le pomenski, skladenjski razvoj nosilcev vezljivosti, temveč so odvisne tudi od drugih jezikovnih vplivanj, predvsem od oblikoskladenjskega in pomenskega razvoja določil oz. njihovih realizacij (Korhonen 2006: 1463-1469, $1471-1472) .^{10}$

\subsection{Prispevek H. Orzechowske k vezavnostni obravnavi slovenskih glagolov védenja}

H. Orzechowska se je v 70. letih 20. st. (Orzechowska 1972, 1974) posvetila vezavi sopomenskih glagolov pslov. *uměti, *věděti, *znati. Avtorica je domnevala, da se pomenski razvoj in spreminjanje rabe sopomenskih glagolov

${ }^{7}$ Določila so lahko na levi ali desni strani nosilca vezljivosti: t. i. levi vezljivosti pripadajo določila $v$ funkciji osebka (lahko tudi logičnega osebka), desni vezljivosti pa ostala določila. Na ločevanje obeh opozarja že J. Toporišič (prim. 1982: 82-119).

${ }^{8}$ Kot stabilen se obravnava gradivsko dobro izkazan vzorec, ki se pojavlja v načeloma daljšem časovnem obdobju (za krajše obdobje mora biti zelo dobro izpričan). Nestabilen vzorec je šibko izkazan in se pojavlja v krajšem časovnem obdobju; kot nestabilni se obravnavajo tudi vzorci, ki se pojavljajo v daljših obdobjih, a so izkazani z osamljenimi zgledi. Ob nekoliko fragmentarnem korpusu je treba računati z neizkazovanjem vezljivostnih možnosti v posameznih obdobjih. »Vezljivostne praznine« se zapolnijo, če je možnost izkazana $\mathrm{v}$ predhodnih in kasnejših obdobjih.

${ }^{9}$ Kompleksna vezljivostna analiza je izpostavljena tudi kot nujna etapa v rekonstrukciji leksikalnega pomena besede. I. Němec vidi v pomensko, skladenjsko in leksikalno opredeljenih udeležencih/določilih t. i. vezljivostne seme, ki so sestavni deli pomenske zgradbe nosilca vezljivosti in omogočajo ustrezno rekonstrukcijo njegovega leksikalnega pomena (Němec 1994: 375-376).

${ }^{10}$ Spremembe vezljivosti so lahko povezane še s fonetičnimi spremembami, ki povzročijo sklonski sinkretizem in privedejo do reanalize sklonov, s težnjo po analitičnosti (Ágel 2000: 271-273), s tujejezičnim vplivom (Hudeček 2001, 2003; Korhonen 2006) itn. 
zrcalita v vezavnostni specializaciji. Odraze omenjenih glagolov v nekaj slov. jezikih (stcsl., pol., slk., sln.) je analizirala v odnosu do vezavnostnih možnosti SAK, INF, SENT in predložnosklonska vezava.

Za sln. avtorica navaja pogostnostno razporeditev vedeti $>\underline{\text { znati }}>\underline{\text { umeti }}$ (slednji naj bi v 20. st. izginil, tudi na račun sestavljenke razumeti). Glagol umeti izkazuje vezavo z INF (od 16. st. njegov delež pri vezavi upada), manj pa je zgledov za SAK (npr. De bodo pak ty, kir ga bujle nevmejo ali nesnajo enu podvishanje inu navuk imeli DB) in SENT (predvsem 19. st., npr. videti je bilo, da so dobro umeli, kaj je hotel neznani pesnik /.../ v besede vložiti F. Erjavec). Najpogostejši vedeti zaznamujejo vse vezavnostne možnosti: pri predložnosklonski vezavi $^{11}$ in SENT močno prevladuje (16.-20. st.), medtem ko delež glagola pri INF sčasoma upade zaradi »prevzema« vezave s strani znati, v primeru SAK pa ga od 17.-18. st. izpodriva poznati. Glagol znati postane dominanten v vezavi z INF (jslov. značilnost); pri SAK ga nadomesti poznati (kot pri vedeti), vezava s SENT pa naj bi bila narečna (vpliv hrv. narečij; prim. Orzechowska 1974).

Ugotovitve H. Orzechowske bi lahko dopolnili predvsem z upoštevanjem vseh določilnih možnosti in $\mathrm{z}$ osvetlitvijo vezave glagolov skozi pomensko usmerjenost. ${ }^{12}$

\section{Pomenje glagolov védenja}

\subsection{Pomenje glagolov umeti in umevati}

Sln. uméti, úmem, stil. uméjem dov./nedov. izkazuje primerljiva pomena (1) 'razumeti, dojeti' in (2) 'znati, biti sposoben, moči'; SSKJ ga označuje kot starinskega (za 20. st.; prim. Plet. II: 715; SSKJ: 1455). ${ }^{13}$

Od 2. pol. 19. st. naprej je izpričan tudi k uméti tvorjen drugotni nedov. umévati, - am (prim. nedov. na -vati; Vaillant 1966: 484) s pomenom (1) 'razumevati, dojemati' (SSKJ: 1456; tudi Plet. II: 715); starejše gradivo ga ne izpričuje.

${ }^{11}$ Pri predložnosklonski vezavi gre za naslednje možnosti: v 16. st. (DB) ODSGEN in ZASAK (70 oz. $30 \%$ ), v 20. st. ZASAK in oSLOK (55 oz. 45 \%; Orzechowska 1974: 145).

${ }^{12}$ Zgodovinskovezljivostno so bili tovrstni glagoli obravnavni tudi za druge slov. jezike, a raziskave nudijo samo delni vpogled v problematiko, prim. Hudeček $(2001,2003)$ za hrv., Maier (2006) in Krys'ko (2006) za rus.

${ }^{13}$ Sln. umẹ́ti, -ẹjem, -ệm (nedov.) 'razumeti, znati' k pslov. *umèti 'umeti, biti sposoben' iz pslov. sam. *umъ゙; ide. *(H)au-mó- '(čutno) dojemanje' iz korena *(H)au - 'čutno dojemati' (Be IV: 263; Snoj 2003: 798). 


\subsection{Pomenje glagola vedeti}

Sln. védeti, vém nedov. izkazuje primerljive pomene (1) 'vedeti', (2) 'znati' in (3) 'poznati'; pomena (2) in (3) naj bi bila v 20. st. starinska (prim. Plet. II: 744-745; SSKJ: 1496-1497). ${ }^{14}$

\subsection{Pomenje glagola znati}

Sln. znáti, znám nedov. izkazuje primerljive pomene (1) 'znati, biti izveden v; utegniti, moči', (2) 'poznati', (3) 'vedeti' ter (4) 'biti videti' (brezos.); pomeni (2), (3) in (4) so v SSKJ označeni s časovnima kvalifikatorjema star. ali zastar. (prim. Plet. II: 942; SSKJ: 1680). ${ }^{15}$

\subsection{Primerljivi pomeni glagolov védenja}

Sln. glagoli védenja izkazujejo naslednje primerljive pomene:

Tabela 1: Primerljivi pomeni glagolov védenja

\begin{tabular}{|l|c|c|c|c|}
\hline & umeti & umevati & vedeti & znati \\
\hline a. 'razumeti, dojeti' & $(1)$ & $(1)$ & & \\
\hline b. 'znati, biti sposoben, moči' & $(2)$ & & $(2)$ & $(1)$ \\
\hline c. 'vedeti' & & & $(1)$ & $(3)$ \\
\hline d. 'poznati' & & & $(3)$ & $(2)$ \\
\hline e. 'biti videti' & & & & (4) \\
\hline
\end{tabular}

\section{Vezljivostne značilnosti glagolov védenja}

\subsection{Pomen a. 'razumeti, dojeti'}

Pomen 'razumeti, dojeti' izkazujeta glagola umeti (1) in umevati (1). V primeru umeti je pomen potrjen od 16. st. do 1. pol. 20. st., pri umevati pa so zgledi iz 19. st. in 1. pol. 20. st. Že od 16. st. v pomenu prevladujeta glagola zastopiti, razumeti (od 19. st. predvsem slednji).

${ }^{14} \mathrm{~S}$ ln. védeti, vém (nedov.) k pslov. *vĕděti, *vě(d)mb" 'vem', kar je prilagojeno iz *vĕdě 'vem' (prim. stcsl. vědě 'vem', rus. vedb 'vendar, pač, saj', prekm. sln. véj 'saj'); slednje je izvorno nereduplicirani perfekt *uóid- $h_{2} a$ (medialno *uóid- $\left.h_{2} a-i\right)$ iz ide. baze *ueid'gledati, videti'. Prim. tudi *víděti (Be IV: 288; Snoj 2003: 810, 819).

${ }^{15}$ Sln. znáti, znâm (nedov.) k pslov. *znäti, kar je iz ide. baze *ǵnoh - 'vedeti, znati, spoznati' (Be IV: 419-420; Snoj 2003: 857). 
2.1.1 Vezljivost pri pomenu a. 'razumeti, dojeti'

Tabela $2:{ }^{16}$ Vezavnostne možnosti pomena a. 'razumeti, dojeti'

\begin{tabular}{|l|c|c|}
\hline & umeti & umevati \\
\hline SNOM - VF - SAK & $16 .-20$. st. & 19.-20. st. \\
\hline SNOM - VF - SENT & $19 .-20$. st. & 20. st. \\
\hline SNOM - VF - ADV & $16 .-20$. st. & \\
\hline
\end{tabular}

Oba (bolj) stabilna vezavnostna vzorca, tj. SNOM - VF - SAK in SNOM - VF ADV, zaznamujeta umeti (16.-20. st.; pomenski vzorec nosilec razumevanja - vsebina).

Med manj stabilnimi vzorci oba glagola izkazujeta le SNOM - VF - SENT (19.-20. st.), nestabilen je tudi vzorec SNOM - VF - SAK ob umevati (19.-20. st.).

Najpogostejše določilo SAK nastopa kot vsebinski udeleženec nepropozicijskega tipa, ${ }^{17}$ najredkejše SENT pa kot vsebinski udeleženec propozicijskega tipa; SENT sicer najbolje razkriva kompleksno vsebino védenjske dejavnosti. ${ }^{18}$ Posebno pozornost si zasluži ADV kot vsebinsko določilo ob predvidljivi leksikalni zapolnitvi - 'razumeti jezik' (prim. 2.3.1).

Med konkurenčnima glagoloma v pomenu 'razumeti, dojeti' prevladuje umeti, izpeljanka umevati je marginalna, kar se kaže v njeni omejeni gradivski zastopanosti (tudi časovno).

Zgledi: SNOM - VF - SAK (umeti 16. st. Inu ty /.../ ne umeio inu ne zastopio tiga catehizma /.../ TAr [III, 39]; 20. st. Nisem ga umel, ker je govoril nemško. SSKJ; umevati 19. st. Božje besede umeva. Ravn.-Valj. [Plet. II: 715]; 20. st. Težko umeva zapletene stvari. SSKJ); SNOM - VF - SENT (umeti 19. st. /.../ ne umejo, kaj je Bog ž njim namenil /.../ Modr 4.17 W; 20. st. Mislim, da umeš, kaj hočem. SSKJ $;{ }^{19}$ umevati 20. st. Počasi umevam, kaj to pomeni. SSKJ); SNOM - VF - ADV (umeti 16. st. /.../ drukar nei slovenski umel /.../ TC 1550 [I, 329]; 20. st. Francosko ume, govori pa ne. SSKJ).

${ }^{16}$ V tabelah 2-5 so temneje označeni (bolj) stabilni, svetleje pa manj stabilni ali nestabilni vezavnostni vzorci.

${ }^{17}$ SAK ima lahko kot tipična vezavna oblika na podlagi oblikoslovnih meril status sistemsko nezaznamovanega izraznega sredstva; posledica tega je usmeritev sln. v tožilniško vezljivost (Dular 1982: 162; Žele 2001: 78-79).

${ }^{18} \mathrm{Na}$ redkost SENT je morda vplivalo to, da se je umeti $\mathrm{v}$ 19. st. vezljivostno približal stabilnejši sestavljenki razumeti in se odmikal od starejšega stanja, ko je bila vezljivostna specializacija umeti pogojena $\mathrm{z}$ razmerji v sopomenski skupini z vedeti in znati.

${ }^{19} \mathrm{~V}$ gradivu je tudi zgled, kjer sta ob umeti (a) SAK in SENT (19. st. Nista še namreč uméla pisma, de je imel od mertvih vstati. J $20.9 \mathrm{~W}$ ), pri čemer je SENT verjetno pristavčno pojasnilo k SAK pismo. Zaradi osamljenosti zgleda in sprejemljivosti razlage s površinskoskladenjskim preoblikovanjem izključujem možnost, da bi šlo za ločen vezavnostni vZorec SNOM - VF - SAK - SENT. 


\subsection{Pomen b. 'znati, biti sposoben, moči'}

Pomen 'znati, biti sposoben, moči' izkazujejo glagoli umeti (2), vedeti (2) in znati (1). Pri vedeti in znati je pomen potrjen od 16. do 21. st., medtem ko je ob umeti izkazan z redkimi zgledi iz 16. st. in 1. pol. 20. st. Glagol vedeti ne izkazuje podpomena 'moči', kar pa ne vpliva na vezljivostne značilnosti.

2.2.1 Vezljivost pri pomenu b. 'znati, biti sposoben, moči'

Tabela 3: Vezavnostne možnosti pomena b. 'znati, biti sposoben, moči'

\begin{tabular}{|l|c|c|c|}
\hline & umeti & vedeti & znati \\
\hline SNOM - VF - SAK & $16 ., 20$. st. & 20. st. & $16 .-20$. st. \\
\hline SNOM - VF - INF & $16 ., 20$. st. & $16 .-20$. st. & $16 .-20$. st. \\
\hline SNOM - VF - ADV & & $18 .-19$. st. & $16 .-20$. st. \\
\hline
\end{tabular}

Med (bolj) stabilnimi vezavnostnimi vzorci le enega izkazujeta dva glagola: SNOM - VF - INF je izpričan ob vedeti (do 1. pol. 20. st.) in znati (do danes). Vzorca SNOM - VF - SAK // ADV sta stabilna le ob znati (16.-20. st.). Vsi ustrezajo pomenskemu razmerju nosilec znanja, zmožnosti - vsebina.

Nestabilni vzorci so enaki stabilnim, njihova nestabilnost pa je vezana na posamezen glagol: na umeti, prim. SNOM - VF - SAK, SNOM - VF - INF (16., 20. st.), in vedeti, prim. SNOM - VF - SAK (20. st.), SNOM - VF - ADV (18.-19. st.).

Določilo SAK nastopa kot vsebinski udeleženec nepropozicijskega tipa (predvsem pri vedeti bi lahko nekatere zglede pripisali pomenu (c)), pogostejši INF pa kot propozicijska vsebina znanja, zmožnosti. Glagoli v pomenu (b) kažejo na pomožniško vlogo (Toporišič 2004: 587) in zahtevajo določilo INF, ki ne predstavlja pretvorbne možnosti SENT ob določenih slovničnih pogojih (npr. enakost osebka glavnega in odvisnega stavka, istodobnost). ${ }^{20}$ Ponovno je najbolj zanimivo ADV: pri znati ima vlogo pravega vsebinskega udeleženca (ob predvidljivi leksikalni zapolnitvi, tj. 'znati, obvladati jezik'), ob vedeti pa gre za t. i. nadomestno določilo, ki predstavlja neeksplicitno vsebino; zaimenski (količinski, kakovostni) prislovi besedilno zapolnjujejo mesto, predvideno za kompleksnejšo realizacijo vsebine znanja (npr. SENT, INF). Prim. tudi 2.3.1.

${ }^{20}$ Sem uvrščam tudi zglede ob t. i. dvigovalnem znati (20. st. Zunaj bi ga znal kdo videti. SSKJ; Ta jed bi znala škoditi. VSSG), ki bi jih v skladu z generativnim jezikoslovjem moral uvrstiti k tipu VF - INF, saj v tem primeru osebku udeleženske vloge ne pripiše znati, ampak nedoločniška zveza v polstavku (Bolta 1986: 427). Zglede uvrščam k tipu SNOM - VF - INF, ker sta kljub temu ob pomenu 'utegniti, moči' realizirani obe poziciji, SNom in INF (čeprav SNom omogoča »dvigovalnost« glagola, ne pa vezljivost znati). V gradivu je še zgled z umeti in zaimenskim SAK, ki napoveduje vsebinski INF, prim. 16. st. En oča umei obuie, tu ie, serditi inu lubiti. TO [III, 516]; INF ima vlogo pojasnila k SAK obuie. 
Med glagoli s pomenom 'znati, biti sposoben, moči' je dominanten zna$\underline{t i}$, manj stabilen je vedeti, ki je že na koncu 19. st. v tem pomenu arhaičen; gradivsko najšibkejši je umeti. Med tremi vezavnostnimi možnostmi je treba izpostaviti predvsem SNOM - VF - INF, medtem ko sta vzorca SNOM - VF - SAK // ADV manj izrazita.

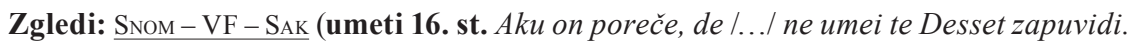
TO [III, 542]; 20. st. Dobro ume svoj posel. SSKJ; vedeti 20. st. Ali še veš to pesem? SSKJ; Vse ve. VSSG; znati 16. st. /.../ zna inu zastopi ta celi catehismus /.../ TAr [III, 130]; 17. st. /.../ v fakateri Purgar je mogal en antverh, ali dellu fnati /.../ SJJSv; 20. st. Igralci ne znajo vlog. SSKJ); SNOM - VF - INF (umeti 16. st. /.../ tvoji hlapci vmejo lejs fékati na Libani. 2 Krn 2.8 DB; 20. st. Še tega ne ume narediti. SSKJ; vedeti 16. st. /.../ de bode veidel nemu prou služiti /.../ TC 1550 [I, 24]; 20. st. Kaj veš svetovati. SSKJ; znati 16. st. Ieft snam vmoriti inu oshiviti /.../ $5 \mathrm{Mz} 32.39 \mathrm{DB}$; 18. st. Je pak blisu unu majhinu meftu, kamèr snam sbejshati /.../ $1 \mathrm{Mz} 19.20 \mathrm{Jap} ;$ 20. st. Otrok pri tej starosti že zna govoriti. SSKJ); SNOM - VF - ADV (znati 16. st. Snafhli Gerzhki? Apd 21.37 DB; 19. st. Znaš greško? W; vedeti 18. st. Vy imate varihe, pojdite, obvarujte, kakòr vejfte. Mt 27.65 Jap).

\subsection{Pomen c. 'vedeti'}

Pomen 'vedeti' izkazujeta glagola vedeti (1) in znati (3). Pri glagolu vedeti je pomen potrjen od predknj. obdobja do 21. st., glagol znati pa ga izkazuje med 16. st. in 1. pol. 20. st.

2.3.1 Vezljivost pri pomenu c. 'vedeti'

Tabela 4: Vezavnostne možnosti pomena c. 'vedeti'

\begin{tabular}{|l|c|c|}
\hline & vedeti & znati \\
\hline SNOM - VF - SAK & $16 .-20$. st. & \\
\hline SNOM - VF - ZASAK & $16 .-20$. st. & 17., 20. st. \\
\hline SNOM - VF - ODSGEN & $16 .-18$. st. & \\
\hline SNOM - VF - OSLOK & 20. st. & \\
\hline SNOM - VF - INF & $16 .-20$. st. & 17. st. \\
\hline SNOM - VF - SENT & predknj. obd. -20. st. & 16.-20. st. \\
\hline SNOM - VF - ODSGEN - SAK* & $16 .-19$. st. & \\
\hline SNOM - VF - ZASTRANSGEN - SAK* & 19. st. & \\
\hline SNOM - VF - OSLOK - SAK* & 20. st. & \\
\hline SNOM - VF - ZASAK - SENT & $16 .-20$. st. & \\
\hline SNOM - VF - ODSGEN - SENT & $16 .-19$. st. & \\
\hline SNOM - VF - OSLOK - SENT & 20. st. & \\
\hline SNOM - VF - ADV & $16 .-20$. st. & \\
\hline
\end{tabular}


Med stabilnimi vezavnostnimi vzorci oba glagola izkazujeta SNOM - VF SENT, ki ustreza pomenskemu vzorcu nosilec védenja - vsebina (do vključno 20. st.).

Ostali stabilni vzorci zaznamujejo le vedeti. Zgornjemu pomenskemu razmerju ustrezajo vezavnostni vzorci SNOM - VF - SAK, SNOM - VF - ZASAK in SNOM - VF - INF (16.-20. st.), razmerju nosilec védenja - razmerni vsebinski udeleženec - vsebina pa SNOM - VF - odSGEN // OSLOK - SAK*, SNOM - VF - ODSGEN // OSLOK - SENT in SNOM - VF - ZASAK - SENT (16.-20. st.). Ob glagolu znati sta vezavnostna vzorca z določiloma ZASAK (17., 20. st.) in INF (17. st.) nestabilna.

Drugi nestabilni vezavnostni vzorci so samo ob vedeti. Pomenskemu razmerju nosilec védenja - vsebina ustrezajo SNOM - VF - oDSGEN // oSLOK (prvi 16.-18. st., drugi 20. st.) in SNOM - VF - ADV (16.-20. st.), razmerju nosilec védenja - razmerni vsebinski udeleženec - vsebina pa SNOM - VF - ZASTRANSGEN - SAK* (19. st.).

Določilo SENT pokriva vlogo vsebinskega udeleženca propozicijskega tipa in je najbolj ustaljena oblika za izražanje kompleksne vsebine védenja; redkejši INF se tu razlaga kot različica SENT ob enakosti osebka glavnega in odvisnega stavka (ta se pretvori v INF) in načeloma istodobnosti. ${ }^{21}$ ADV kot t. i. nadomestno določilo predstavlja neeksplicitno vsebino; zaimenski (količinski, kakovostni) prislovi besedilno zapolnjujejo mesto, predvideno za kompleksnejšo realizacijo vsebine védenja (npr. SENT; prim. VV: 161). Določilo ADV je lahko tudi del desnih določilnih možnosti (SAK), pri tem vsebino nominalizira in se približa $\mathrm{SAK}^{22}$ Večinoma količinski prislovi so prekrivni z zaimenskimi neprislovnimi prvinami. $^{23}$

Na mestu določila SAK kot vsebinskega udeleženca nepropozicijskega tipa (t. i. diktum) so večinoma zaimki ali samostalniki z zelo ekstenzivnim pomenom (tip reč, stvar), kar kaže na njegovo »nadomestno« vlogo - tovrstni SAK nadomešča kompleksnejšo vsebino, tj. SENT (Dular 1982: 182). Leksikalna zapolnitev predložnosklonskega zASAK, z vlogo razmernega vsebinskega udeleženca (t. i. siže), je bogatejša. Enako vlogo imata nekoliko redkejši določili oDSGEN in

${ }^{21} \mathrm{Ob}$ vedeti (1) prevladuje določilo INF tipa Ne ve kaj reči (indirektna vprašanja; prim. še znati (3)), ki ga ob enakosti osebka glavnega in odvisnega stavka zaznamujeta zadobnost (manj istodobnost), pogojno-želelna modalnost (pretvorba Ne ve, kaj bi rekel), morda namernost. Ta tip vsebinskega določila INF so problematizirali npr. za češ. že V. Zikmund (1863: 405), za rus. pa A. A. Potebnja (1874: 383-387; 397-398).

${ }^{22}$ Prim. oddaljevanje ADV oz. SAK* od vloge povedkovega dopolnila in približevanje določilu: znati grščino - grško; veš, da sem doma - to - tako; veš o njem, da ne živi $\underline{t u}-\underline{\text { dosti }}-\underline{t o}$. Na močnejšo določilno vlogo kaže naslednje: (1) vloga konkretizatorja sporočila se krepi, na kar vpliva večja pomenskoskladenjska obveznost; (2) slabi lastnostno opredeljevanje 'vedenja' (bolj vsebinski pomen), kolokacijsko stabilne zveze; (3) glagoli odpirajo vezljivostna mesta, ki jih ne zasedajo pričakovana določila, temveč ADV. Glede na obnašanje ADV oz. SAK* menim, da se pojavlja na položaju določila: kot pravi vsebinski udeleženec ali kot t. i. nadomestno določilo (prim. Ágel 2000: 261; Žele 2003: 30; Žele 2007). Prim. še 2.1.1 in 2.2.1.

${ }^{23}$ Oznaka SAK* zastopa prislovne in sopomenske, s prvimi načeloma zamenljive neprislovne oblike, ki besedilno nadomeščajo kompleksnejše »vsebinsko« določilo. 
oSLOK, ki sta bolj pogosti v vzorcih z več desnimi določili. Tu naj opozorim na zanimivo razmerje med njima - v 19. st. se oDSGEN umakne določilu oSLOK, kar je najbrž rezultat vzpostavitve knjižnojezikovne norme, ki je skušala odstraniti tujejezične oz. neslovanske prvine iz sln. knjižnega jezika (za hrv. jezik Hudeček 2003). Določilo odSGEn je bilo še v 19. st. ustaljeno ob glagolih sporočanja, čutenja (tudi védenja), danes pa je le pogovorna oz. narečna možnost (Orel 1993; Dular 1982: 188-189). ${ }^{24}$ Najredkejše določilo z vlogo razmernega vsebinskega udeleženca je zastranSGen. ${ }^{25}$

Pri 'vedeti' je dominanten glagol vedeti, ki je gradivsko dobro potrjen in vezljivostno najbolj »aktiven«. Osamljeni zgledi in zgolj tri vezavnostne možnosti opozarjajo, da je imel pomen 'vedeti' pri znati marginalno postavitev.

Med vezavnostnimi vzorci prevladuje SNOM - VF - SENT, ki ustreza kompleksnemu značaju vsebine védenja. Ob vezavnostnih vzorcih, ki kažejo na razmerje nosilec védenja - vsebina, pa so ob vedeti tudi takšni, ki ustrezajo pomenskemu razmerju nosilec védenja - razmerni vsebinski udeleženec-vsebina.

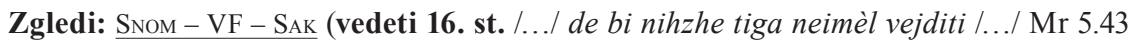
DB; 17. st. Letu je dobru vejdla Rimska Gospa Lugretia. SJJSv; 20. st. To dobro vedo poklicni šoferji. SSKJ); $\mathrm{S}_{\mathrm{NOM}}-\mathrm{VF}$ - ZASAK (vedeti 16. st. Ti vejfh sa moje sashmaganje /.../ Ps 69.20 DB; 20. st. Ali veš za kakega dobrega obrtnika? SSKJ; znati 17. st. /.../ nej fo ludje sa ta dua greha snali. SJJSv; 20. st. Za njegov dolg so znali vsi. SSKJ); SNOM - VF - ODSGEN (vedeti 16. st. /.../ ne veido od obene druge brume inu pravice /.../ TAr [III, 103]; 18. st. On /.../ je tebi Manno k'jędi dal, od katęre nifi vęjdil /.../ $5 \mathrm{Mz} 8.3$ Jap); SNOM - VF - OSLOK (vedeti 20. st. O tem bodo vedeli neposredno vpleteni. VSSG); SNOM - VF - INF (vedeti 18. st. Vy od lenobe ne vejfte kaj sazhęti /.../ 2 Mz 5.17 Jap; 20. st. Bil je zmeden, da ni vedel kaj reči. SSKJ; znati 17. st. /.../ nefnamo koku sazheti /.../ SJJSv); SNOM - VF - SENT (vedeti predknj. obd. Ti edin, Bose, vuez, caco mi ie iega potreba vuelica. BS [I, 20-21]; 18. st. Inu vy dve famę vęjfte, de fim is zęle moje mozhy vajmu ozhętu flushil. $1 \mathrm{Mz} 31.6$ Jap; 20. st. Vem, da si bil doma. SSKJ; znati 16. st. Iest ne sem znal, de te žele so greh /.../ TC 1555 [I, 419]; 20. st. Znaj, da pri nas to ni dovoljeno. SSKJ); SNOM - VF - ODSGEN - SAK* (vedeti 16. st. Od tiga Boga inu nega vole ti haidye, Turki, sadašni Judye ništer ne vedeyo /.../ TC 1550 [III, 48]; 19. st. Lažnjivi možje nič ne vedo od nje /.../ Sir $15.8 \mathrm{~W}$ ); SNOM - VF - ZASTRANSGEN - SAK* (vedeti 19. st. /.../ tvoj hlapec ni nič vedil zastran té reči /.../ 1 Sam $22.15 \mathrm{~W}) ; \underline{\text { SNOM }-V F-O S L O K}$ - SAK* (vedeti 20. st. Več bodo vedeli o tem sosedje. SSKJ); SNOM - VF - ZASAK - SENT (vedeti 16. st. /.../ imaio za risnico veiditi, de so v nemilosti inu v serdu Božym. TO [III, 271]; 20. st. Zanj vem, da bo zmogel. SSKJ); SNOM - VF - ODSGEN - SENT (vedeti 18. st. Sakaj od letiga vuka my vejmo, de fe njemu povfód supèr govory. Apd 28.22

${ }^{24}$ F. Kopečný (1973: 154) opozarja, da je predmetni otъS $\mathrm{GEN}_{\mathrm{G}}$ 'o’ v stčeš., dluž. (manj gluž.), sln., csl. in stsbh. najbrž latinizem, ki ga je v prostorih germansko-slovanskega stika podpiral vpliv nemščine (ni čisti germanizem, kot meni J. Gebauer). Zgodovinskojezikovno je pri отъSGEN primaren ločilniški pomen, izhodiščni pomen oSLOK je bil verjetno 'okoli', pri zASAK pa odtenek smernosti oz. ciljnosti (Kopečný 1973: 132, 150, 283-284).

${ }^{25}$ Sln. zastràn z oziralnim pomenom (Kopečný 1973: 243) nastane iz predložne zveze *za + stôrnb; pri pslov. *stôrnb se izhaja iz pomena *'nekaj ploskega, prostranega' (Snoj 2003: 702), za pa kaže na smernost (Kopečný 1973: 284, 286-287). Enako določilno vrednost bi v sod. sln. imela zveza GLEDESGEN (Dular 1982: 199-200). 
Jap; 19. st. /.../ od kateriga so vedili, de je pervak na kraljevim dvoru /.../ Est 9.4 W); SNOM - VF - oSLOK - SENT (vedeti 20. st. O izpitu vem, da je težak. [prim. Dular 1982: 205]); SNOM - VF - ADV (vedeti 16. st. Ieft fedim ali vftanem, taku ti vejfh, ti saftopifh moje mifli od dalezh. Ps 139.2 DB; 20. st. Ve dosti, mnogo. VSSG).

\subsection{Pomen d. 'poznati'}

Pomen 'poznati' izkazujeta glagola vedeti (3) in znati (2), in sicer od 16. st. do 1. pol. 20. st. (od 18. st. se začne v tem pomenu uveljavljati sestavljenka poznati).

2.4.1 Vezljivost pri pomenu d. 'poznati'

Tabela 5: Vezavnostne možnosti pomena d. 'poznati'

\begin{tabular}{|l|c|c|}
\hline & vedeti & znati \\
\hline Snom - VF - Sak & $16 .-20$. st. & $16 .-20$. st. \\
\hline Snom - VF - Sak - SENT & $16 ., 19$. st. & 16. st. \\
\hline
\end{tabular}

Stabilen vezavnostni vzorec ob obeh glagolih je SNOM - VF - SAK (16.-20. st.), ki ustreza pomenskemu razmerju nosilec poznavanja - vsebina.

Tudi nestabilen vzorec SNOM - VF - SAK - SENT je prisoten ob vedeti (16., 19. st.) in znati (16. st.), ustreza pa razmerju nosilec poznavanja - prizadeto - vsebina (določilo SENT se približuje predikativni vlogi). Osamljeni zgledi pričajo o tem, da je bilo zadnje vezljivostno razmerje v okviru pomena 'poznati' marginalno.

Določilo SAK v vlogi vsebine poznavanja je dobro izpričano do 18. st., v 19.-20. st. pa je zgledov ob omenjenih glagolih precej manj.

V pomenu 'poznati' se vedeti, znati vsaj od 18. st. umikata sestavljenki poznati, kar vpliva na vezljivost glagola (prim. Orzechowska 1974). Domnevam, da je bil vzorec SNOM - VF - SAK ob vedeti, znati 'poznati' stabilen le do 20. st. (v SSKJ je pomen ob obeh označen kot starinski).

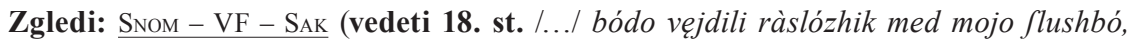
inu med flushbó posęmelfkiga krajlętva. 2 Krn 12.8 Jap; 20. st. Umetnika, ki je sliko naredil, ne vemo. SSKJ; znati 16. st. Bug sna vafha ferza. Lk $16.15 \mathrm{DB} ; 20$. st. Zna njegove skrivnosti. SSKJ); SNOM - VF - SAK - SENT (vedeti 16. st. /.../ imaio te uržahe inu tudi te trošte veiditi, de tacih missal /.../ ne bodo imeili /.../ TO [III, 304]; 19. st. Gospod vé misli človekove, de so nečimerne. Ps $93.11 \mathrm{~W}$; znati 16. st. Ony fo ga tudi snali, de je on ta bil, kir je pred lepimi Daurmi tiga Templa fedil /.../ Apd 3.10 DB).

\subsection{Pomen e. 'biti videti'}

Pomen 'biti videti' ima le znati (4); na njegovo obrobno postavitev pri glagolu opozarjajo redki zgledi iz 18.-20. st. (v 20. st. je zastarel; SSKJ: 1680).

Pomenskemu vzorcu s prizadetim z zaznavanjem ustrezata manj stabilna vezavnostna vzorca brez levega določila (glagol ne predvideva »levega« 
udeleženca); bolj ustaljen je VF - SAK (18.-20. st.), VF - SENT je izkazan le z zgledom iz 20. st. Določilo SAK nastopa kot prizadeto z zaznavanjem, SENT pa kot kompleksnejša vsebina zaznavanja.

Zgledi: $\mathrm{VF}$ - $\mathrm{SAK}_{\mathrm{AK}}$ (18. st. /.../ ny nobeniga snámina nje pôti snáti /.../ Mdr 5.11 Jap; 20. st. Nikjer ni bilo znati človeških bivališč. SSKJ); VF - SENT (20. st. Na obrazu mu je bilo znati, kaj čuti. SSKJ).

\section{Sklep}

Sln. glagoli védenja umeti, umevati, vedeti in znati so leksikalno zapletena skupina. Razen umevati so vsi večpomenski in se pomensko pogosto prekrivajo - pomen 'znati' zaznamuje glagole umeti, vedeti in znati, pomena 'vedeti' in 'poznati' se pojavljata pri vedeti in znati, prim. delno prekrivnost pomenja umeti in umevati. Nek pomen lahko glagoli izkazujejo v vsej zgodovinski dobi jezika (npr. vedeti 'vedeti'), pomen lahko pri glagolu v času slabi, medtem pa se znotraj pomena krepi vloga drugega glagola (tako se od 18. st. glagola vedeti in znati $\mathrm{v}$ pomenu 'poznati' umikata sestavljenki poznati), lahko pa ima glagol v pomenu ves čas šibkejšo vlogo (npr. 'razumeti, dojeti' ter odnos umeti, umevati do dominantnejših zastopiti, razumeti). Med glagoli se po pomenih lahko vzpostavijo konkurenčna razmerja, ki se razrešujejo $\mathrm{v}$ prid dominantnih glagolov.

Vezljivostna analiza je pokazala, da različni pomeni oblikujejo specifične pomenske vzorce, ki jim ustreza načeloma več vezavnostnih vzorcev; konkurenčna razmerja med vzorci pa se razrešujejo v korist stabilnejših. Analiza je tudi pokazala, da glagoli lahko oblikujejo pomenske in vezavnostne vzorce, ki jih pri drugih glagolih v istem pomenu ni (dopolnitev mnenja A. Goldberg). Analiza je nadgradila dosedanje razprave o vezavi sln. védenjskih glagolov H. Orzechowske, saj je konkurenčna razmerja med njimi osvetlila s pomočjo pomenske usmerjenosti in upoštevala vse vezavnostne možnosti (tudi kompleksnejše).

Najbolj zanimiva konkurenčna razmerja med glagoli se vzpostavljajo v pomenih 'znati', 'vedeti' in 'poznati'. V pomenu 'znati' je dominanten glagol zhati, manj vedeti (na koncu 19. st. arhaičen), najšibkejši je umeti. Najstabilnejši med tremi vezavnostnimi vzorci, ki ustrezajo pomenskemu razmerju nosilec znanja - vsebina, je SNOM - VF - INF (stabilen predvsem pri znati in vedeti), vzorca SNOM - VF - SAK // ADV pa sta manj pogosta. V pomenu 'vedeti' prevladuje gradivsko dobro izkazan in vezljivostno najbolj raznovrsten glagol vedeti; pri znati se pomen kot neustaljen ohranja do 1. pol. 20. st. Najbolj ustaljeno pomensko razmerje pri 'vedeti' je nosilec védenja - vsebina, ki mu med vezavnostnimi vzorci ustreza predvsem SNom - VF - SENT (ob obeh glagolih); SENT torej najbolj stabilno zaznamuje kompleksno vsebino védenja (določila $\mathrm{S}_{\mathrm{AK}}$, ZASAK in INF mu konkurirajo predvsem ob vedeti). Le ob vedeti se pojavljajo tudi vezavnostni vzorci, ki ustrezajo kompleksnejšemu pomenskemu razmerju nosilec védenja - razmerni vsebinski udeleženec - vsebina, prim. predvsem stabilne SNOM - VF - ODSGEN - SAK* // SENT (16.-19. st.), SNOM - VF - OSLOK - SAK* 
// SENT (20. st.), SNOM - VF - ZASAK - SENT (16.-20. st.). V pomenu 'poznati' se konkurenčno razmerje med glagoli vedeti, znati in poznati razrešuje v korist zadnjega (vsaj od 18. st.). Dominantnemu pomenskemu vzorcu nosilec poznavanja - vsebina ustreza vezavnostni vzorec SNOM - VF - SAK (do 20. st.). V pomenu 'poznati' se v 16. st. (manj v 19. st.) pojavljajo tudi osamljeni zgledi vezavnostnega vzorca SNOM - VF - SAK - SENT, ki kažejo na pomensko razmerje nosilec poznavanja - prizadeto - vsebina.

Med glagoli védenja sta najredkejša umeti ter umevati. V pomenu 'znati' se prvi umika glagoloma znati in vedeti, v pomenu 'razumeti' pa se oba umikata dominantnima zastopiti in razumeti. Predvsem ob umeti (pogostejši od umevati) sta v pomenu 'razumeti' bolj stabilna vezavnostna vzorca SNOM - VF - SAK // ADV, ki ustrezata pomenskemu razmerju nosilec razumevanja - vsebina (16.-20. st.; nestabilen je vzorec $\mathrm{z}$ določilom SENT).

Pomenskim vzorcem ustreza načeloma več vezavnostnih vzorcev, ki vstopajo v konkurenčna razmerja (prim. predvsem določila) in ki lahko kažejo na pomenske razlike. Ob vedeti 'vedeti' v vlogi vsebinskega udeleženca propozicijskega tipa prevladuje določilo SENT (od predknj. obdobja do danes), ki mu konkurira nekoliko redkejši INF. Med določili nepropozicijskega tipa je prevladujoče ZASAK (16.-20. st.), redkejši sta oDSGEN (16.-18. st.) in oSLOK (20. st.); pogosto je tudi določilo SAK, ki pa je večinoma zasedeno z zaimki ali s samostalniki zelo ekstenzivnega pomena in tako kaže na »nadomestno« vlogo (nadomešča kompleksnejše SENT). Zanimiva vezavnostna razmerja so tudi pri pomenskem vzorcu nosilec védenja - razmerni vsebinski udeleženec - vsebina, prim. SNOM - VF - ODSGEN - SAK* // SENT (16.-19. st.), SNOM - VF - OSLOK - SAK*// SENT (20. st.), SNOM - VF - ZASAK - SENT (16.-20. st.) in SNOM - VF - ZASTRANSGEN - SAK* (19. st.). Zopet je treba opozoriti na določila $\mathrm{z}$ vlogo razmernega vsebinskega udeleženca: najstabilnejše je zASAK, nato ODSGEN in oSLOK, nestabilno pa zastranSGen. Problemsko najzanimivejše je razmerje med odSGEn in oSLoK - v 19. st. je namreč na mestu razmernega vsebinskega udeleženca zadnje nadomestilo prvega. Sprememba je bila verjetno posledica vzpostavljanja norme, ki ni bila naklonjena tujejezičnim oz. neslovanskim prvinam v knjižnem jeziku.

$\mathrm{Ob}$ sln. glagolih védenja ima posebno vezljivostno vlogo tudi prislovno določilo ADV oz. SAK*; v vlogi pravega vsebinskega udeleženca se pojavlja ob umeti, znati (pomena 'razumeti jezik' in 'znati, obvladati jezik'), kot t. i. nadomestno določilo pa ob vedeti (pomena 'vedeti' in 'znati').

\section{KRAJŠAVE (DOLOČILA)}

$\mathrm{SNOM}_{\mathrm{N}}=$ samostalnik $\mathrm{v}$ imenovalniku $(\mathrm{GEN}=$ rodilnik; $\mathrm{DAT}=$ dajalnik; $\mathrm{AK}=$ tožilnik; $\mathrm{LOK}$ $=$ mestnik; $\mathrm{INS}=$ orodnik); $\mathrm{oDSGEN}_{\mathrm{G}}=$ predložnosklonska oblika samostalnika s predložnim morfemom OD in rodilniško obliko (npr. NASAK, POSLOK); SENT = odvisnik; INF = nedoločnik; ADV = prislov. 


\section{VIRI IN LITERATURA}

BS $=$ France BERNIK idr. (ur.), 2004: Brižinski spomeniki $=$ Monumenta Frisigensia. Ljubljana: Založba ZRC, ZRC SAZU.

DB = Jurij DALMATIN, (1584) 2004: BIBLIA, TV IE, VSE SVETV PISMV, STARIGA inu Noviga Teftamenta. Biblia slovenica (CD-ROM). Ur. Anton Metelko. Ljubljana: Svetopisemska družba Slovenije.

Jap = Jurij JAPELJ idr., (1784-1802) 2004: SVETU PISMU STARIGA INU NOVIGA TESTAMENTA. Biblia slovenica (CD-ROM). Ur. Anton Metelko. Ljubljana: Svetopisemska družba Slovenije.

Nikolai MIKHAILOV, 1998: Frühslowenische Sprachdenkmäler. Die handschriftliche Periode der slowenischen Sprache (XIV. Jh. Bis 1550). Amsterdam, Atlanta: Rodopi.

Preš. = Peter SCHERBER, 1977: Slovar Prešernovega pesniškega jezika . Maribor: Obzorja.

Plet. $=$ Maks PLETERŠNIK, (1894-1895) 2006: Slovensko-nemški slovar I-II. Ur. Metka Furlan. Ljubljana: Založba ZRC SAZU, ZRC SAZU.

SJJSv = Marko SNOJ, 2006: Slovar jezika Janeza Svetokriškega 1-2. Ljubljana: SAZU. SSKJ = Anton BAJEC idr. (ur.), 1998: Slovar slovenskega knjižnega jezika. Ljubljana: SAZU oz. ZRC SAZU (izd.) - DZS (zal.).

TA = Primož TRUBAR, (1550) 2002: Abecedarium. Zbrana dela Primoža Trubarja I. Ur. Igor Grdina, Fanika Kranjc-Vrečko. Ljubljana: Rokus. 281-308.

TAr = Primož TRUBAR, (1562) 2005: Articuli oli deili te prave, stare vere kersčanske. Zbrana dela Primoža Trubarja III. Ur. Igor Grdina, Jonatan Vinkler. Ljubljana: Rokus. $5-224$.

TC 1550 = Primož TRUBAR (1550) 2002: Catechismus. Zbrana dela Primoža Trubarja I. Ur. Igor Grdina, Fanika Kranjc-Vrečko. Ljubljana: Rokus. 19-278.

TO = Primož TRUBAR, (1564) 2005: Cerkovna ordninga. Zbrana dela Primoža Trubarja III. Ur. Igor Grdina, Jonatan Vinkler. Ljubljana: Rokus, 227-578.

VSSG = Andreja ŽELE, 2008: Vezljivostni slovar slovenskih glagolov. Ljubljana: Založba ZRC, ZRC SAZU.

$\mathrm{W}=$ Anton A. WOLF (pobud.), (1856-1859) 2004: Sveto pismo stare in nove zaveze. Biblia slovenica (CD-ROM). Ur. Anton Metelko. Ljubljana: Svetopisemska družba Slovenije.

Vilmos ÁGEL, 2000: Valenztheorie. Tübingen: Gunter Narr Verlag.

Robert-Alain de BEAUGRANDE, Wolfgang U. DRESSLER, 1992: Uvod v besediloslovje. Ljubljana: Park.

$\mathrm{Be}=$ France BEZLAJ idr., 1976-2007: Etimološki slovar slovenskega jezika I-V. Ljubljana: SAZU (izd.) - Mladinska knjiga (zal.).

Marija BOLTA, 1986: Slovenski glagoli z nedoločniškim dopolnilom v tvorbeno-pretvorbenem pristopu. Slavistična revija 34/4, 419-431. 
Janez DULAR, 1982: Priglagolska vezava v slovenskem knjižnem jeziku (20. stoletja). Doktorska disertacija. Ljubljana.

José M. ${ }^{a}$ GARCÍA-MIGUEL, Susana COMESAÑA, 2004: Verbs of cognition in Spanish: Constructional schemas and reference points. Linguagem, Cultura e Cogniçao: Estudios de Linguística Cognitiva. Ur. Augusto S. da Silva idr. Coimbra: Almedina. 399-420.

Adele E. GOLDBERG, 2006: Constructions at Work: The Nature of Generalizations in Language. Oxford: OUP.

Katrin GÖTZ-VOTTELER, 2007: Describing semantic valency. Valency: Theoretical, Descriptive and Cognitive Issues. Ur. Thomas Herbst idr. Berlin, New York: Mouton de Gruyter. 37-49.

Thomas HERBST, 2007: Valency complements or valency patterns? Valency: Theoretical, Descriptive and Cognitive Issues. Ur. Thomas Herbst idr. Berlin, New York: Mouton de Gruyter, 15-35.

--, 2009: Valency - Item-Specifity and Idiom Principle. Exploring the Lexis-Grammar Interface. Ur. Ute Römer idr. Amsterdam, Philadelphia: Benjamins. 49-68.

Hans J. HERINGER, 2006: Prinzipien des Valenzwandels. Dependenz und ValenzDependency and Valency. 2. Halbband. Ur. Vilmos Ágel idr. Berlin, New York: Walter de Gruyter. 1447-1461.

Lana HUDEČEK, 2001: Glagoli govorenja i mišljenja u hrvatskome čakavskom književnom jeziku do 17. stoljeća - strani sintaktički utjecaji. Rasprave Instituta za hrvatski jezik i jezikoslovlje 27, 95-112.

- -, 2003: Dopune glagolima govorenja, mišljenja i srodnih značenja u hrvatskome književnom jeziku od 17. do polovice 19. stoljeća - strani sintaktički utjecaji. Rasprave Instituta za hrvatski jezik i jezikoslovlje 29, 103-129.

Stanisław KAROLAK, 1984: Składnia wyrażeń predykatywnych. Gramatyka współczesnego języka polskiego. Składnia. Ur. Zuzanna Topolińska. Warszawa: PWN. 11-211.

František KOPEČNÝ, 1973: Etymologický slovnik slovanských jazyků I. Praha: Academia.

Jarmo KORHONEN: Valenzwandel am Beispiel des Deutschen. Dependenz und Valenz - Dependency and Valency. 2. Halbband. Ur. Vilmos Ágel idr. Berlin, New York: Walter de Gruyter. 1462-1474.

Vadim B. KRYS'KO, 2006: Исторический синтаксис русского языка. Объект и переходность. Москва: Издательский центр Азбуковник.

Ingrid MAIER, 2006: Verbalrektion in den »Vesti-Kuranty« (1600-1660). Teil 2: Die präpositionale Rektion. Uppsala: Uppsala University Library.

Igor NĚMEC, 1994: The Potential Valency Constituent in Diachronic Lexicology. The Syntax of sentence and text: a festschrift for František Daneš. Ur. Světla Čmejrková idr. Amsterdam, Philadelphia: Benjamins. 373-382.

Irena OREL-POGAČNIK, 1993: Predložni sistem v razvoju slovenskega knjižnega jezika od 16. do 19. stoletja. Doktorska disertacija. Ljubljana.

Janez OREŠNIK, 1992: Udeleženske vloge v slovenščini. Ljubljana: SAZU. 
Hanna ORZECHOWSKA, 1972: Zmiany rekcji czasowników *umèti, *věděti, *znati w językach zachodniosłowiańskich i ich rekcja w języku słowieńskim. Studia z filologii polskiej i słowiańskiej XI, 235-248.

- -, 1974: Vezava glagolov *věděti, *znati, *uměti v Dalmatinovi bibliji in današnji slovenščini. Slavistična revija 22/2, 129-149.

Aleksandr A. POTEBNJA, 1874: Изъ записокъ по русской грамматикъ I-II. Воронеж. SČ = Miroslav GREPL, Petr KARLÍK, 1998: Skladba češtiny. Olomouc: Votobia.

Marko SNOJ, 2003: Slovenski etimološki slovar. Ljubljana: Modrijan.

SPP = Nad'a SVOZILOVÁ idr., 1997: Slovesa pro praxi. Praha: Academia.

SSG = Kazimierz POLAŃSKI idr., 1980-1992: Stownik syntaktyczno-generatywny czasowników polskich I-V. Wrocław, Kraków: Zakład Narodowy im. Ossolińskich, Instytut Języka Polskiego PAN.

Jože TOPORIŠIČ, 1982: Nova slovenska skladnja. Ljubljana: DZS.

- -, 2004: Slovenska slovnica. Maribor: Založba Obzorja.

André VAILLANT, 1966: Grammaire comparée des langues slaves III. Le verbe. Paris: Éditions Klincksieck.

Ada VIDOVIČ-MUHA, 2000: Slovensko leksikalno pomenoslovje. Ljubljana: Znanstveni inštitut Filozofske fakultete.

VV = František DANEŠ idr., 1987: Větné vzorce v češtině. Praha: Academia.

Václav ZIKMUND, 1863: Skladba jazyka českého. Litomyšl, Praha.

Andreja ŽELE, 2001: Vezljivost v slovenskem jeziku (s poudarkom na glagolu). Ljubljana: Založba ZRC, ZRC SAZU.

- -, 2003: Vezljivost kot pomenskoskladenjski pokazatelj živosti slovenščine. Slovenski knjižni jezik-aktualna vprašanja in zgodovinske izkušnje (Obdobja 20). Ur. Ada Vidovič Muha. Ljubljana: Filozofska fakulteta. 423-433.

--, 2007: Povedkova lastnostna prislovna dopolnila. Slavistična revija 55/1-2, 369-387.

\section{THE VALENCY OF THE VERBS OF KNOWING IN THE HISTORY OF SLOVENIAN LITERARY LANGUAGE}

The paper presents the results of a valency analysis of the verbs of knowing umeti, umevati, vedeti and znati in the history of Slovenian literary language. The verbs form a lexically complex group: all the verbs (with the exception of umevati) are polysemic and their meanings generally overlap. The most unstable verbs in the group are umeti, umevati, as they tend to be replaced by more dominant verbs: in the case of the meaning 'to know, be able to' by the verb znati, in the case of 'to understand' by zastopiti and razumeti.

Changes in the meaning of verbs correspond to changes in their valency and government. Within a particular meaning specific semantic patterns are formed, to which multiple 
government patterns generally correspond. In the case of the meaning 'to know, be aware of' the most stable semantic pattern is carrier of knowledge - content, the predominant corresponding government pattern being SNOM - VF - SENT; the complement SENT is thus the most stable form used for expressing a complex content of knowledge (complements SACC, ZASACC and INF are somewhat less stable and can be found primarily with the verb vedeti). For the meaning 'to know, be able to' (the dominant verb is znati, less stable is vedeti, while umeti is the weakest verb with this meaning) with the semantic pattern carrier of knowing, ability - content, the historically most stable government pattern is SNOM - VF - INF. Among more complex government patterns (in general less frequent), the most stable ones are those corresponding to the semantic pattern carrier of knowledge - thematic participant - content (literally to know - about somebody, something - something), cf. SNOM - VF - ODSGEN - SACC* / SENT (up to the $2^{\text {nd }}$ half of the $19^{\text {th }}$ c.), SNOM - VF - oSLOC - SACC* $/ /$ SENT (after the $2^{\text {nd }}$ half of the $19^{\text {th }}$ c.) and SNOM $\mathrm{VF}-$ ZASACC - SENT $\left(16^{\text {th }}-20^{\text {th }} \mathrm{c}\right.$. $)$.

Competitive relationships may arise among government patterns (especially among right complements). The most interesting competitive relationship is the one between the right complements with the semantic role of content of knowledge in the case of the verb vedeti 'to know, be aware of': the complement SENT predominates (to date), competing mainly with a more sporadic INF (the content participant of the sentential type); on the other hand, the complement SACC $\left(16^{\text {th }}-20^{\text {th }} \mathrm{c}\right.$.), which is also stable, functions as a so-called substitute complement - it is represented mostly by pronouns and nouns with semantically extensive meanings, that substitute the complement SENT. Also stable is the complement ZASACC $\left(16^{\text {th }}-20^{\text {th }} \mathrm{c}\right.$.), but as representing the thematic content participant it competes above all with less stable oDSGEN $\left(16^{\text {th }}-18^{\text {th }} \mathrm{c}\right.$. $)$ and oS LoC $\left(20^{\text {th }} \mathrm{c}\right.$. $)$. In the case of the last two complements, it has to be mentioned that in the $19^{\text {th }} \mathrm{c}$., in the role of the thematic content participant, oSLoc replaced the complement ODSGEN (the change points to the formation of a linguistic standard opposed to foreign or non-Slavic elements). The analysis has also drawn attention to the valency value of the adverbial complement ADV (also SACC*), which can function as a real content argument (cf. the meanings 'to understand a language' and 'to master a language') and as a so-called substitute complement. 